Abstract THU0189 - Table 1. Baseline characteristics

\begin{tabular}{|c|c|c|c|c|c|c|c|c|c|}
\hline & \multicolumn{3}{|c|}{$\begin{array}{c}\text { Switchers } \\
n=1621\end{array}$} & \multicolumn{3}{|c|}{$\begin{array}{c}\text { Non-switchers } \\
n=440\end{array}$} & \multicolumn{3}{|c|}{ p-value } \\
\hline & $\begin{array}{c}\mathrm{RA} \\
\mathrm{n}=933 \\
(58 \%) \\
\end{array}$ & $\begin{array}{c}\text { PsA } \\
n=351 \\
(22 \%) \\
\end{array}$ & $\begin{array}{c}\text { AxSpA } \\
n=337 \\
(21 \%) \\
\end{array}$ & $\begin{array}{c}\text { RA } \\
n=286 \\
(65 \%) \\
\end{array}$ & $\begin{array}{c}\text { PsA } \\
n=56(13 \%)\end{array}$ & $\begin{array}{c}\mathrm{AxSpA} \\
\mathrm{n}=98(22 \%)\end{array}$ & RA & PsA & AxSpA \\
\hline Female, $\%$ & 74 & 46 & 34 & 76 & 55 & 35 & 0.5 & 0.2 & 0.9 \\
\hline Age, yrs & $61\left({ }^{49-70}\right.$ & $52\left({ }^{43-61}\right.$ & $48\left(^{39-57}\right.$ & $62\left({ }^{48-70}\right.$ & $52\left(^{43-58}\right.$ & $48\left(^{40-57}\right.$ & 0.8 & 0.8 & 0.8 \\
\hline Concomitant MTX,\% & 60 & 48 & 15 & 49 & 30 & 18 & $<0.01$ & 0.02 & 0.4 \\
\hline In remission,\%* & 65 & 70 & 28 & 55 & 73 & 21 & $<0.01$ & 0.6 & 0.2 \\
\hline Pt global<30 mm,\% & 52 & 51 & 51 & 45 & 43 & 42 & 0.03 & 0.3 & 0.1 \\
\hline DAS28 & $\begin{array}{c}2.1(1.6- \\
3.0)\end{array}$ & $\begin{array}{c}2.0(1.6- \\
2.8)\end{array}$ & - & $\begin{array}{c}2.5(1.8- \\
3.3)\end{array}$ & $\begin{array}{c}2.0(1.8- \\
2.8)\end{array}$ & - & $<0.01$ & 0.5 & - \\
\hline $\mathrm{HAQ}$ & $\begin{array}{c}0.8(0.3- \\
1.3)\end{array}$ & $\begin{array}{c}0.5(0.0- \\
1.0)\end{array}$ & $\begin{array}{c}0.4(0.0- \\
0.8)\end{array}$ & $\begin{array}{c}0.9(0.4- \\
1.5)\end{array}$ & $\begin{array}{c}0.8(0.6- \\
1.3)\end{array}$ & $0.4(0-0.9)$ & $<0.01$ & 0.07 & 0.3 \\
\hline $\begin{array}{l}\text { Recieved } 25 \text { mg ETA/inj, } \\
\%\end{array}$ & 1 & 1 & 1 & 44 & 19 & 39 & $<0.01$ & $<0.01$ & $<0.01$ \\
\hline Prior ETA duration, yrs & $\begin{array}{c}6.0(3.6- \\
8.6)\end{array}$ & $\begin{array}{c}4.3(2.9- \\
7.3)\end{array}$ & $\begin{array}{c}4.6(2.8- \\
6.8)\end{array}$ & $\begin{array}{c}5.3(2.4- \\
8.6)\end{array}$ & $\begin{array}{c}3.4(1.6- \\
6.0)\end{array}$ & $\begin{array}{c}4.7(2.9- \\
9.0)\end{array}$ & 0.01 & 0.02 & 0.3 \\
\hline
\end{tabular}

standard care, leading to withdrawal from ineffective therapy in both switchers and non-switchers.

Acknowledgements: Partly sponsered by Biogen

Disclosure of Interest: B. Glintborg Grant/research support from: Abbvie, Biogen, Pfizer, I. Sørensen: None declared, E. Omerovic: None declared, F. Mehnert: None declared, N. Manilo: None declared, K. Danebod: None declared, D. Jensen: None declared, H. Nordin: None declared, A. G. Loft Grant/research support from: AbbVie, MSD, Novartis, Pfizer, Roche, UCB, O. Hendricks Grant/research support from:: Abbvie, Roche, Novartis, S. Chrysidis: None declared, B. Andersen: None declared, J. Raun: None declared, H. Lindegaard: None declared, J. Espesen: None declared, S. Jakobsen: None declared, I. M. Hansen Grant/ research support from: Roche, E. Dalsgaard: None declared, D. Pedersen: None declared, S. Kristensen: None declared, A. Linauskas: None declared, L. Andersen: None declared, J. Grydehøj: None declared, N. Krogh: None declared, M. Hetland Grant/research support from: Abbvie, Biogen, BMS, CellTrion, MSD, Novartis, Orion, Pfizer, Samsung, UCB

DOI: 10.1136/annrheumdis-2018-eular.2113

\section{THU0190 CLINICAL OUTCOMES AMONG RHEUMATOID ARTHRITIS PATIENTS RECEIVING ADALIMUMAB WHO DID OR DID NOT PARTICIPATE IN THE PATIENT SUPPORT PROGRAM: A SUBANALYSIS OF THE PASSION STUDY}

A. Ostor ${ }^{1}$, S. Wassenberg ${ }^{2}$, P. Zueger ${ }^{3}$, J. Kalabic ${ }^{4}, M . W^{3}$, I. Lagunes Galindo ${ }^{3}$, F. Van den Bosch ${ }^{5} .{ }^{1}$ Cabrini Medical Centre, Melbourne, Australia;

${ }^{2}$ Rheumazentrum Ratingen, Ratingen, Germany; ${ }^{3} \mathrm{AbbVie}, \mathrm{N}$ Chicago, USA;

${ }^{4}$ AbbVie Deutschland Co. GmbH, Ludwigshafen, Germany, ${ }^{5}$ Ghent University

Hospital, Ghent, Belgium

Background: The AbbVie Patient (pt) Support Program (PSP) is offered to pts prescribed adalimumab (ADA) for rheumatoid arthritis (RA) and other indications. Objectives: This subanalysis evaluated the impact of ADA in achieving clinical, functional, and pt-reported outcome treatment targets and sustained responses by PSP use.

Methods: PASSION was a 78-wk postmarketing, multinational, observational study enrolling pts with moderate to severe RA receiving ADA in routine clinical care. Pts with an insufficient response to $\geq 1$ disease modifying antirheumatic drug (DMARD; 1 prior biologic DMARD was allowed) and newly initiating ADA were enrolled. Pts were divided into 2 groups based on PSP participation: ever (PSP users) vs never (PSP non-users). Outcome measures included proportion of pts with low disease activity (LDA)/remission defined by Clinical Disease Activity Index $(C D A I) \leq 10$, Simplified Disease Activity Index (SDAI) $\leq 11$, and Disease Activity Score(DAS)28(C-reactive protein $[\mathrm{CRP}]) \leq 3.2$; proportion with mild to moderate disability (Health Assessment Questionnaire Disease Index [HAQ-DI] 0 to 1); and proportion with $20 \% / 50 \% / 70 \%$ improvement from baseline (BL) in ACR components (table 1). Missing values were imputed using last observation carried forward, and differences in proportions between PSP users and PSP non-users were compared with Chi-square tests.

Results: Of 1025 pts treated with ADA in the study, 499 were PSP users and 526 were PSP non-users. A significantly greater proportion of PSP users vs PSP nonusers had LDA/remission as defined by CDAl at wks 24, 52, and 78 and as defined by SDAI or DAS28(CRP) at weeks 52 and 78 ( $p<0.05$ for all). A significantly greater proportion of PSP users vs PSP non-users also had mild to moderate disability defined by HAQ-DI at wk $78(\mathrm{p}=0.0239)$. Compared with PSP nonusers, a significantly greater proportion of PSP users had $70 \%$ improvement from BL in PtGA, pain, and CRP at wks 24, 52, and 78; SJC28 at wks 52 and 78; and TJC28 and PhGA at wk 78 (table 1). At wks 24, 52, and 78, a significantly greater proportion of PSP users vs PSP non-users had $20 \%$ and $50 \%$ improvements from $\mathrm{BL}$ in all $\mathrm{ACR}$ components (all $\mathrm{p}<0.05$ ), except for $50 \%$ improvement from $\mathrm{BL}$ in TJC28 at wks 24 and 78 and PhGA at wk 24.

Abstract THU0190 - Table 1. Proportion of Patients With 70\% Improvement in ACR Individual Components (LOCF) by PSP Utilisation Category by Visit (Intent-To-Treat Population)

\begin{tabular}{|c|c|c|c|c|}
\hline & Visit & $\begin{array}{c}\text { PSP User } \\
\text { n/N (\%) }\end{array}$ & $\begin{array}{c}\text { PSP Non-user } \\
\mathrm{n} / \mathrm{N}(\%)\end{array}$ & $P$-value \\
\hline \multirow{3}{*}{$\begin{array}{l}\text { TJC28 70\% improvement } \\
\text { from baseline }\end{array}$} & Week 24 & $278 / 482(57.7)$ & $270 / 508(53.2)$ & 0.1521 \\
\hline & Week 52 & $281 / 482(58.3)$ & $266 / 508(52.4)$ & 0.0604 \\
\hline & Week 78 & $296 / 482(61.4)$ & $277 / 508(54.5)$ & $0.0284^{*}$ \\
\hline \multirow{3}{*}{$\begin{array}{l}\mathrm{SJC} 28 \mathrm{70} \% \text { improvement } \\
\text { from baseline }\end{array}$} & Week 24 & $313 / 482(64.9)$ & $300 / 508(59.1)$ & 0.0568 \\
\hline & Week 52 & $326 / 482(67.6)$ & $306 / 508(60.2)$ & $0.0154^{*}$ \\
\hline & Week 78 & $327 / 482(67.8)$ & $299 / 508$ (58.9) & $0.0034^{* * *}$ \\
\hline \multirow{3}{*}{$\begin{array}{l}\text { PtGA 70\% improvement } \\
\text { from baseline }\end{array}$} & Week 24 & $154 / 497(31.0)$ & $100 / 518(19.3)$ & $<0.0001^{* * *}$ \\
\hline & Week 52 & $171 / 497(34.4)$ & $119 / 518(23.0)$ & $<0.0001^{* * *}$ \\
\hline & Week 78 & $187 / 497$ & & $<0.0001^{* * *}$ \\
\hline \multirow{3}{*}{$\begin{array}{l}\text { PhGA } 70 \% \text { improvement } \\
\text { from baseline }\end{array}$} & Week 24 & $183 / 461(39.7)$ & $202 / 512(39.5)$ & 0.9383 \\
\hline & Week 52 & $209 / 461(45.3)$ & $207 / 512(40.4)$ & 0.1224 \\
\hline & Week 78 & $229 / 461(49.7)$ & $210 / 512(41.0)$ & $0.0067^{* *}$ \\
\hline \multirow{3}{*}{$\begin{array}{l}\text { Pain } 70 \% \text { improvement } \\
\text { from baseline }\end{array}$} & Week 24 & $151 / 497(30.4)$ & $95 / 519(18.3)$ & $<0.0001^{* * *}$ \\
\hline & Week 52 & $172 / 497$ & $117 / 5$ & $<0.0001^{* * *}$ \\
\hline & Week 78 & $190 / 497$ & 132 & $<0.0001^{* * *}$ \\
\hline \multirow{3}{*}{$\begin{array}{l}\text { CRP } 70 \% \text { improvement } \\
\text { from baseline }\end{array}$} & Week 24 & $173 / 4$ & $129 /$ & $<0.0001^{* * *}$ \\
\hline & Week 52 & $166 / 455(36.5)$ & $134 / 494(27.1)$ & $0.002^{* *}$ \\
\hline & Week 78 & $173 / 455(38.0)$ & $150 / 494(30.4)$ & $0.0129 *$ \\
\hline \multicolumn{5}{|c|}{$\begin{array}{l}\text { The intent-to-treat (ITT) population includes patients who received } \geq 1 \text { dose of study drug. } \\
\mathrm{n}=\text { number of patients in the ITT population; } \mathrm{N}=\text { number of patients with non-missing values at each visit. } \\
\text { ***, ***, *, statistically significant at } P<0.001,0.01 \text {, and } 0.05 \text { levels, respectively. } P \text {-values derived from } \\
\text { Chi-square test. } \\
\text { Missing data were imputed for each efficacy endpoint using LOCF. The differences between groups in } \\
\text { efficacy endpoints at wk } 24,52 \text {, and } 78 \text { were based on ANCOVA models adjusting for baseline and } \\
\text { demographic variables (sex, race, ethnicity, age [years], PSP participation [ever (PSP users) vs never (PSP } \\
\text { non-users)], diagnosis RA duration [years]). }\end{array}$} \\
\hline \multicolumn{5}{|c|}{$\begin{array}{l}\text { ANCOVA, analysis of covariance; CRP, C-reactive protein; LOCF, last observation carried forward; Pain, } \\
\text { Patient Global Assessment of Pain; PhGA, Physician Global Assessment of Disease Activity; PtGA, Patient } \\
\text { Global Assessment of Disease Activity; PSP, patient support program; SJC28, Swollen 28-Joint Count; }\end{array}$} \\
\hline
\end{tabular}

Conclusions: Among pts with moderate to severe RA initiating ADA treatment, participation in the PSP resulted in significantly greater improvements in clinical, functional, and pt-reported outcomes at wks 24, 52, and 78 in comparison to the PSP non-users.

Acknowledgements: AbbVie funded the study and analysis, and approved the abstract for submission. Medical writing support was provided by Aric Fader, PhD of Complete Publication Solutions, LLC (North Wales, PA, USA) and was funded by AbbVie.

Disclosure of Interest: A. Ostor Grant/research support from: Lilly, Roche, MSD, AbbVie, Pfizer, Novartis, Janssen, and Bristol-Myers Squibb, Consultant for: Lilly, Roche, MSD, AbbVie, Pfizer, Novartis, Janssen, and Bristol-Myers Squibb, S. Wassenberg Grant/research support from: AbbVie, BMS, Fuji, Gilead, Novartis, Pfizer, Roche, Sandoz, and UCB, Consultant for: AbbVie, Celgene, Janssen, Chugai, Lilly, Novartis, Pfizer, MSD, and UCB, Speakers bureau: 
AbbVie, Celgene, Janssen, Chugai, Lilly, Novartis, Pfizer, MSD, and UCB, P Zueger Employee of: AbbVie, J. Kalabic Employee of: AbbVie, M. Wu Employee of: AbbVie, I. Lagunes Galindo Employee of: AbbVie, F. Van den Bosch Grant/ research support from: AbbVie, Bristol-Myers Squibb, Celgene, Janssen, Lilly, Merck, Novartis, Pfizer, and UCB, Consultant for: AbbVie, Bristol-Myers Squibb, Celgene, Janssen, Lilly, Merck, Novartis, Pfizer, and UCB, Speakers bureau: AbbVie, Bristol-Myers Squibb, Celgene, Janssen, Lilly, Merck, Novartis, Pfizer, and UCB

DOI: 10.1136/annrheumdis-2018-eular.6754

\section{THU0191 NOVEL FORMULATION OF CT-P13 FOR SUBCUTANEOUS ADMINISTRATION IN PATIENTS WITH RHEUMATOID ARTHRITIS: INITIAL RESULTS FROM A PHASE I/III RANDOMISED CONTROLLED TRIAL}

R. Westhovens ${ }^{1}$, D.H. Yoo ${ }^{2}$, J. Jaworski ${ }^{3}$, E. Matyska-Piekarska ${ }^{3}$, S. Smiyan ${ }^{4}$, D. Ivanova ${ }^{5}$, A. Zielinska ${ }^{6}$, E.-K. Raussi ${ }^{7}$, A. Batalov ${ }^{8}$, S.J. Lee ${ }^{9}$, S.Y. Lee ${ }^{9}$, J. H. Suh ${ }^{9} .{ }^{1}$ University Hospital KU Leuven, Leuven, Belgium; ${ }^{2}$ Hanyang University Hospital for Rheumatic Diseases, Seoul, Korea, Republic of Ireland; ${ }^{3}$ REUMATIKA - Centrum Reumatologii NZOZ, Warszawa, Poland; ${ }^{4}$ State Higher Educational Institution "I. Ya. Horbachevskyi Ternopil State Medical University of MOH of Ukraine", Ternopil, Ukraine; ${ }^{5}$ Diagnostic-Consultative Center Aleksandrovska EOOD, Sofia, Bulgaria; ${ }^{6}$ Medycyna Kliniczna, Warszawa, Poland; ${ }^{7}$ North Estonia Medical Centre Foundation, Tallinn, Estonia; ${ }^{8}$ Medical University - Plovdiv, University Hospital Kaspela, Clinic of Rheumatology, Plovdiv, Bulgaria; ${ }^{9}$ Celltrion, Inc., Incheon, Korea, Republic of Ireland

Background: While the treatment with intravenous (IV) CT-P13, an infliximab biosimilar, is effective and well tolerated, a new subcutaneous (SC) CT-P13 formulation (CT-P13 SC) is developed to provide additional, more convenient treatment options and opportunity for self-injection.

Objectives: To find the optimal dose of CT-P13 SC and to evaluate efficacy, PK and safety over the first 30 weeks in patients with rheumatoid arthritis.

Methods: This study consists of 1 cohort with CT-P13 IV, and 3 cohorts with 3 different doses of CT-P13 SC injected biweekly. All enrolled patients initially received CT-P13 IV at Weeks 0 and 2 and patients who received 2 full doses and displayed no safety concerns were randomly assigned to receive either CT-P13 SC or IV at Week 6 . Using part 1 result, PK-PD modelling was conducted for the 3 regimens.

Results: A total of 50 patients were enrolled, of whom 48 patients were randomly assigned into 4 cohorts.

Overall, the efficacy results of CT-P13 SC up to Week 30 were comparable to those of CT-P13 IV. Disease improvement by DAS28 and ACR20 were comparable across all 4 cohorts, regardless of the route of administration or dosage of CTP13 (table 1).

The safety profiles in CT-P13 SC cohorts were generally comparable to CT-P13 IV. One of the 2 patients who experienced a hypersensitivity reaction became anti-drug antibody (ADA) positive at Week 6 and experienced hypersensitivity from Week 2 to 8 . All injection site reactions were grade 1 or 2 . The proportion of ADA (positive) was lower in the SC cohorts.

In PK-PD modelling, bioavailability was 59\% (95\% Cl, 52\%-67\%). The dose linearity in SC regimens was confirmed based on Weeks 22 to $30 \mathrm{C}_{\text {trough }}, \mathrm{AUC}_{\tau}$ and $\mathrm{C}_{\max , \text { ss }}$ (figure 1). $\mathrm{C}_{\text {trough }}$ were greater (above $4 \mu \mathrm{g} / \mathrm{mL}$ ) than the target exposure $(1 \mu \mathrm{g} / \mathrm{mL})^{[1][2]}$ in all SC regimens. There was a trend towards slightly lower DAS28 score in all SC regimens, which was consistent with the higher $\mathrm{C}_{\text {trough }}$ comparing with CT-P13 IV. Based on the exposure-response safety analyses, there was no correlation between $\mathrm{PK}\left(\mathrm{AUC}_{\tau}\right.$ or $\left.\mathrm{C}_{\max }\right)$ and safety (IRRs or infections).

Abstract THU0191 - Table 1. Efficacy and safety up to Week 30

\begin{tabular}{|c|c|c|c|c|c|}
\hline & & $\begin{array}{c}\text { Cohort } 1 \\
\text { IV } 3 \mathrm{mg} / \\
\mathrm{kg} \\
(\mathrm{n}=13)\end{array}$ & $\begin{array}{c}\text { Cohort } \\
2 \\
\text { SC } \\
90 \mathrm{mg} \\
(n=11)\end{array}$ & $\begin{array}{c}\text { Cohort } 3 \\
\text { SC } \\
120 \mathrm{mg} \\
(\mathrm{n}=12)\end{array}$ & $\begin{array}{c}\text { Cohort } 4 \\
\text { SC } \\
180 \mathrm{mg} \\
(\mathrm{n}=12)\end{array}$ \\
\hline \multirow{3}{*}{$\begin{array}{l}\text { DAS28 (CRP), mean } \\
\pm \text { SD }\end{array}$} & Week 0 & $5.4 \pm 0.8$ & $6.3 \pm 0.8$ & $5.7 \pm 0.9$ & $5.5 \pm 0.8$ \\
\hline & Week 6 & $3.9 \pm 1.5$ & $4.6 \pm 1.1$ & $3.9 \pm 1.2$ & $3.4 \pm 1.2$ \\
\hline & Week 22 & $3.9 \pm 1.6$ & $3.7 \pm 1.0$ & $3.3 \pm 1.4$ & $2.8 \pm 1.3$ \\
\hline Week 30 & $3.3 \pm 1.3$ & $3.0 \pm 1.1$ & $3.1 \pm 1.0$ & $2.7 \pm 1.0$ & \\
\hline ACR20, & Week 6 & $8(61.5)$ & $8(72.7)$ & 7 (58.3) & 7 (58.3) \\
\hline \multirow[t]{2}{*}{ n (\%) } & Week 22 & $8(61.5)$ & 8 (72.7) & $9(75.0)$ & $11(91.7)$ \\
\hline & Week 30 & $11(84.6)$ & $\begin{array}{c}10 \\
(90.9)\end{array}$ & $10(83.3)$ & $12(100)$ \\
\hline \multirow[t]{4}{*}{ Safety, n (\%) } & $\begin{array}{l}\text { Hypersensitivity/ } \\
\text { IRR }\end{array}$ & 0 & $1(9.1)$ & $1(8.3)$ & 0 \\
\hline & $\begin{array}{l}\text { Injection site } \\
\text { reactions }\end{array}$ & 0 & 2 (18.2) & 0 & $2(16.7)$ \\
\hline & Infections & $4(30.8)$ & $2(18.2)$ & 0 & $4(33.3)$ \\
\hline & ADA & $9(69.2)$ & $3(27.3)$ & $4(33.3)$ & $1(8.3)$ \\
\hline
\end{tabular}

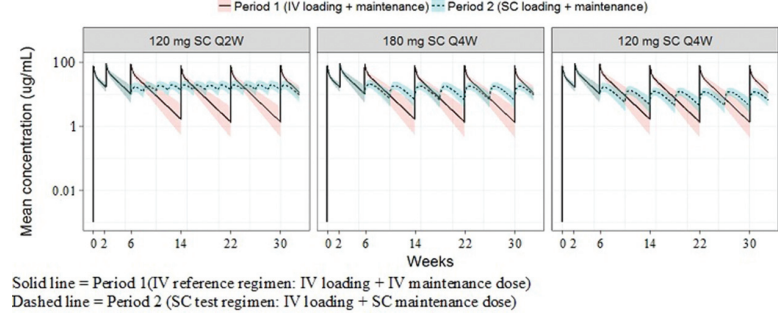

Abstract THU0191 - Figure 1. Mean ( \pm SD) Simulated CT-P13 Serum Concentration vs Time Profiles for the Simulated Fixed Dose SC Maintenance Dosing Regimens with Overlaid IV Maintenance Reference Treatment (Semi-Logarithmic Scale). Solid line=Period 1 (IV reference regimen: IV loading+IV maintenance dose). Dashed line=Period 2 (SC test regimen: IV loading+SC maintenance dose)

Abstract THU0191 - Table 2. Summary of Steady State Median (Prediction Interval $5^{\text {th }}-95^{\text {th }}$ percentile) CT-P13 Exposure Results

\begin{tabular}{|c|c|c|c|}
\hline Simulated Dose Regimen & $\begin{array}{c}C_{\text {trough }} \\
(\mu \mathrm{g} / \mathrm{mL})\end{array}$ & $\begin{array}{l}\text { AUC } 22300 \mathrm{kr} \\
(\mathrm{h} \cdot \mu \mathrm{g} / \mathrm{mL})\end{array}$ & $\begin{array}{c}C_{\max } \\
(\mu \mathrm{g} / \mathrm{mL})\end{array}$ \\
\hline $3 \mathrm{mg} / \mathrm{kg}$ IV every 8 weeks & $\begin{array}{c}1.53 \\
(0.18-5.2)\end{array}$ & $\begin{array}{c}16725.64 \\
(9328.94-26297.08)\end{array}$ & $\begin{array}{c}76.01 \\
(52.73-103.21)\end{array}$ \\
\hline $120 \mathrm{mg} \mathrm{SC}$ every 2 weeks & $\begin{array}{c}13.66 \\
(6.66-24.25)\end{array}$ & $\begin{array}{c}22717.66 \\
(12849.49-37845.41)\end{array}$ & $\begin{array}{c}18.95 \\
(11.38-30.81)\end{array}$ \\
\hline $180 \mathrm{mg} \mathrm{SC}$ every 4 weeks & $\begin{array}{c}6.66 \\
(2.55-13.7)\end{array}$ & $\begin{array}{c}17060.69 \\
(9660.52-28442.43)\end{array}$ & $\begin{array}{c}17.47 \\
(11.13-26.76)\end{array}$ \\
\hline $120 \mathrm{mg} \mathrm{SC}$ every 4 weeks & $\begin{array}{c}4.44 \\
(1.7-9.14)\end{array}$ & $\begin{array}{c}11375.19 \\
(6440.93-18976.74) \\
\end{array}$ & $\begin{array}{c}11.65 \\
(7.42-17.84)\end{array}$ \\
\hline
\end{tabular}

Treatment continuation in patients enrolled with SB4 or oETN who were bionaive until enrollment.

Conclusions: CT-P13 SC showed comparable efficacy and safety with CT-P13 IV. The preliminary results suggest CT-P13 SC as a future alternative treatment of infliximab.

\section{REFERENCES:}

[1] Takeuchi, et al. 2009.

[2] Mori, et al. 2007.

Disclosure of Interest: R. Westhovens Grant/research support from: Celltrion, Inc., BMS and Roche, Consultant for: Celltrion, Inc., Galapagos/Gilead and Janssen, D. H. Yoo Grant/research support from: Celltrion, Inc., J. Jaworski Grant/ research support from: Celltrion, Inc., E. Matyska-Piekarska Grant/research support from: Celltrion, Inc., S. Smiyan Grant/research support from: Celltrion, Inc., D. Ivanova Grant/research support from: Celltrion, Inc., PPD, Quintiles, Egis Pharmaceuticals, and Pfizer., A. Zielinska Grant/research support from: Celltrion, Inc., E.-K. Raussi Grant/research support from: Celltrion, Inc. and Board of Estonian Society for Rheumatology, A. Batalov Grant/research support from: Celltrion, Inc., S. J. Lee Employee of: Celltrion, Inc., S. Y. Lee Employee of: Celltrion, Inc., J. H. Suh Employee of: Celltrion, Inc.

DOI: 10.1136/annrheumdis-2018-eular.1810

\section{THU0192 RETENTION RATES FOR ETANERCEPT: COMPARING THE ORIGINAL WITH A BIOSIMILAR}

A. Strangfeld ${ }^{1}$, L. Baganz ${ }^{1}$, P. Herzer ${ }^{2}$, J. Braun ${ }^{3}$, A. Gräßler ${ }^{4}$, A. Zink ${ }^{1,5} .{ }^{1}$ German $^{2}$ Rheumatism Research Center, Berlin; ${ }^{2}$ Scientific Advisory Board, Munich; ${ }^{3}$ Rheumazentrum Ruhrgebiet, Herne; ${ }^{4}$ Rheumatologist, Pirna; ${ }^{5}$ Charité University Medicine, Berlin, Germany

Background: Since the first approval of a biosimilar in 2015, the number of biosimilars approved for the treatment of rheumatoid arthritis (RA) in Germany has been increasing. Until now, there are just a few analyses investigating retention rates of biosimilars and the respective originators.

Objectives: To compare treatment survival on SB4 to the originator etanercept (oETN) using real-world data.

Methods: We used data gathered until December 2017 from the prospective, longitudinal RABBIT (Rheumatoid Arthritis: Observation of biologic therapy) cohort RA patients are enrolled in RABBIT when they start a biologic, biosimilar or new CsDMARD treatment. For comparative analyses, patients starting SB4 either at enrollment or during follow-up were compared to patients enrolled with oETN since 2015. The drug survival rates during the first six months were analysed in biologic naive patients prior to enrollment using Kaplan-Meier curves. 